\title{
The Contribution of Soil and Water Protection to Household Food Security: The Case of ChehaWoreda, Gurage Zone of Southern Region, Ethiopia
}

\author{
MenurHassen(MSc) Teshome Sirany(MSc) \\ Gurage zone farm and natural resource management office. \\ College of agriculture and natural resources department of rural development and agricultural extension, Debre \\ Markos University.
}

\begin{abstract}
A study was set out to investigate the assessment of the contribution of soil and water conservation to household food security in ChehaWoreda, Gurage Zone of Southern Region Ethiopia. A cross-sectional survey design was used for this specific study. The mixed research approach was employed. In this research stratified random sampling was used to select survey participants. Key informants focus group participants and observation sites were selected using purposive sampling. Data was collected from various sources using a questionnaire survey, key informant interview, focus group discussion and observation. Quantitative data were analyzed using descriptive statistics such as observed counts, frequencies, percentage, cross-tabulation, paired-samples t-test and one way ANOVA. The result revealed that as a coping strategy of solving these problem farmers used mechanical methods such as soil bund, stone bund, Fanyafuu, area closure, cut off drain, waterway, afforestation and terracing; and biological methods of soil and water conservation practices such as chemical fertilizer application, manure application, fallowing, crop rotation and crop residue. Although it is reported that household heads participated in the mechanical methods of soil and water conservation practices, there is a problem in the effective use of biological methods of practice as indicated by some of the farmers. Soil and water conservation has many contributions to household food security. Among these contributions are; increase in animal production, increased crop productivity and production, improved grazing land, increased job opportunities, improve the forest area and increase infrastructure accessibility. Soil and water conservation used to enhance the food security status of the household in the study area. But it needs the more effective use of biological methods of SWC practices and experienced experts.
\end{abstract}

Keywords: Soil, Water, soil degradation, erosion, conservation, Food Security

DOI: $10.7176 /$ CER/12-4-02

Publication date: April $30^{\text {th }} 2020$

\section{Introduction}

\subsection{Background of the Study}

Soil is one of the most essential resources for agriculture. Neely and Sara (2003) located that within the world, about $40 \%$ of agricultural land is extraordinarily degraded, of which $80 \%$ is because of soil erosion. Sanchez (2002) recognized that in recent decades on soil fertility and soil conservation across the world for you to offer sustainable solutions to the rising food and nutrition insecurity while keeping the natural resource base. As Fleitmann et al. (2007) located that soil erosion and land degradation threaten the food security of 2.6 billion human beings worldwide and; this situation is specifically dangerous in East and Sub-Saharan Africa, where according to capita meals manufacturing has declined during the last forty-five years. Erosion and the following loss of fertile soil is a key socio-monetary and ecological problem, affecting all critical sectors of the nation's economy (together with agriculture, manufacturing of hydropower, fisheries, tourism) and negative marine and terrestrial ecosystems. Hence, the utilization of soil calls for sustainable management.

Ethiopia is considered one of the developing nations in sub-Saharan Africa that highly depends on agriculture to fulfil the call for food, fiber and different goods, nevertheless, diminishing productivity, resulting from degradation of agricultural land caused by way of soil erosion, has been and is still a main given attention one (Admasu, 2005; Akllu and Graaff, 2006; Teshome, et.al 2012).

SNNPRsessential resources have been seriously threatened with the aid of human-caused soil and water degradation. Soil and water degradation is severe trouble that contributes to low agricultural productiveness and food security problems. It encompasses soil erosion, soil nutrient depletion, salinity, changes in soil shape and floor and underground water depletion. Soil erosion through runoff is the maximum serious hassle within the region which leads to soil fertility decline and as a result deteriorating productive capacity of the land. The top and fertile part of the land has been eroded by diverse agents in particular through wind and/or water. The nature of livelihood of the farming network coupled with topographic, soil and rainfall distribution behaviour worsen soil and water degradation in SNNPR as nicely as within us of a Panda 2007, referred to in Genene and Abiy (2014). 
Like other parts of Ethiopia, south nation nationality peoples state (SNNPS) agricultural production is dominated through rain-fed agriculture FDRE (2013). The area is heavily tormented by land degradation ensuing in food lack of confidence and rural poverty. Therefore, exploring the contribution of soil and water conservation to improve family meals protection is utmost important. However, the issue is not but studied in detail in the take a look at sites. Thus, the have a look at focuses on to assessing the contribution of soil and water conservation on household food protection in Chehaworeda, Gurage zone.

\subsection{Statement of the Problem}

In the world, approximately 1 to 1 .five billion people are explicitly negatively suffering from land degradation. Healthy land ecosystems are crucial to sustainable development, but land degradation creates trouble including food insecurity and shortage of stepped forward livelihoods. The other effect of land degradation is it creates fast-growing of land prices, because of these it increases shortage of land and high yield prices, and eventually faced by the hassle of to achieve healthful land ecosystems those are crucial to sustainable development, including meal security and stepped forward livelihoods (ELD Initiative, 2013).

According to Holden et al. (2005) in Ethiopia, the time calls for to generate soil fertility is average almost 10 instances the rate of soil erosion and the country's estimated charge of soil nutrient depletion is some of the maxima in Sub-Saharan Africa. It also will increase the farmer's vulnerability to drought by reducing runoff penetration and soil moisture-protecting capacity. The combined effect of low productiveness and environment degradation lock the terrible in the vicious cycle of poverty and environmental degradation (ibid), so soil erosion has occurred due to either exertive utilization of land for communal or individual consumption. Despite the efforts to opposite environmental degradation in the beyond many years, vast degradation of herbal sources continued to be critical environmental trouble in Ethiopia distressing land agricultural productivity and lowering down economic change (FDRE, 2013).

Shebru (2010) diagnosed that the SNNPRs due to the increase of each human and livestock populations have been developing excessive land degradation problems. This situation not most effective undermines agricultural manufacturing capacity. But also it's far a threaten for the environmental sustainability of the region. Decline agricultural productiveness in highland has largely been associated with high population density, deforestation and multi cultivation of step-slops without effective conservation measures.

In ChehaWoredathere's land degradation problem due to natural and man-made activities. Mohammed (2011) performed a look at on the notion of the neighbourhood community in the direction of deforestation and also Mohammed (2014) studied on soil fertility popularity in the observed area. However, those researchers have not integrated the contribution of soil and water conservation practices for meals security. As a long way as the researcher know-how is concerned there is no research conducted in the observe area regarding the position of water and soil conservation for food security.

\subsection{The objective of the Study}

\subsubsection{General Objective of the Study}

The general objective of the study is to investigate the contribution of soil and water conservation to household food security.

\section{The Specific objectives of the study}

1. To explore soil and water conservation practices in the study area.

2. To assess the contribution of soil and water conservation practices to household food security in the study site.

\subsection{Research Question}

1. What are the mechanical and biological methods of soil and water conservation practices?

2. Do soil and water conservation practices contributed to household food security?

\subsection{Scope/Delimitation of the Study}

This study assessed the contribution of soil and water conservation practice to the household food security in particular and food security of the study area in general. The researcher assessed the study area that has three agro-ecology zones by selecting two Kebeles from each of lowland, midland and two highlands. In this study, the participants were sampled female and male-headed farmers, key informant interviewees and focus group discussants.

\subsection{Significance of the Study}

This research is intended to contribute as the baseline information in the study area. This particular study could serve as a baseline study for development intervention (e.g. awareness creation, capacity building, problem and technology prioritization) and further research in the issue of soil and water conservation impact on the 
livelihood of the farming community. Furthermore, the study could update the contribution of soil and water conservation practices to household food security in the study area.

\subsection{Limitation of the Study}

The study is limited to focus on the contribution of soil and water conservation practices to household food security. As a result, the quality of information gathered through a structured survey questionnaire depends on willingness, recalling capacity and knowledge of the respondents. The researcher has also faced financial limitation. In addition to these, the study suffers from material problems and shortage of time. In order to conduct a mixed form of research, there is a great deal of data collection involved that is more complex.

\section{RESEARCH METHODOLOGY}

\subsection{Study Area}

This study was conducted in Chehaworeda located about $185 \mathrm{kms}$ southeast of the capital city, Addis Ababa. Found between $8^{\circ} 82^{\prime}$ ' longitude and $37^{\circ} 38^{\prime}$ latitude. The altitude of the study district ranges from $1900 \mathrm{~m}$ to $3000 \mathrm{~m}$ a.s.1.

\subsection{Research Design}

In order to examine the research questions and the practical reality in the study site, the researchers have used the cross-sectional research design.

\subsection{Sampling Procedure and Sample Size Determination}

Stratified random sampling technique applied to select the six Kebeles of the study area, due to the presence of three agro-ecology, first differentiate each Kebeles respective agro-ecology then the researcher taken two Kebeles in each agro-ecology randomly. This is due to get the effective representation of the 39 rural kebeles of the study area. The last sampling technique used in the selection of the participant household heads in the survey assessment. Yemane (1967) provides an easy method to calculate sample sizes at a 95\% level of a confidence interval, with a 0.05 level of precision. The sample size was determined as follows.

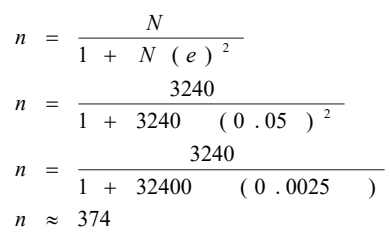

\subsection{Data Type and Sources}

The researcher used primary and secondary sources to find reliable and valid data. The primary sources were sampled household, the farm and natural resources management office of the Woreda, Kebelesand Woreda administration office. The secondary source of this study used published and unpublished documents such as articles, journals, internet, books, research papers, office documents and reports.

\subsection{Method of Data Collection Procedures}

Survey Questionnaire: - A structured survey questionnaire was prepared earlier to conduct the study so as to collect important data on the demographic, socio-cultural, economic and institutional characteristics of sample households.

Focus Group Discussion (FGD): - a checklist to collect helpful information was set and used.

Key Informant's Interview (KII):- individuals who are knowledgeable about soil and water conservation contacted and discussion was held with them.

\section{RESULTS AND DISCUSSION}

\subsection{Physical Method of Soil and Water Conservation}

\subsubsection{Stone Bunds}

Stone bunds are one of the physical methods of soil and water conservation practice to lessen and stop the velocity of runoff, soil erosion, and to increase soil fertility and crop yield. The respondents spoke back that $84.5 \%, 62.1 \%$ and $23.6 \%$ of highland, midland and lowland respectively as participated inside the stone bunds practices. In the examine area, stone bund became practised highly in the highland and midland part, this changed into because of the availability stone. Key informants said that stone bund is constructed by using stone and gabion as a height of $60-70 \mathrm{~cm}$ up to100 $\mathrm{cm}$ and top width of $30-40 \mathrm{~cm}$, and also this bund needs to be spaced difficult for animals to cross (see figure 1). 

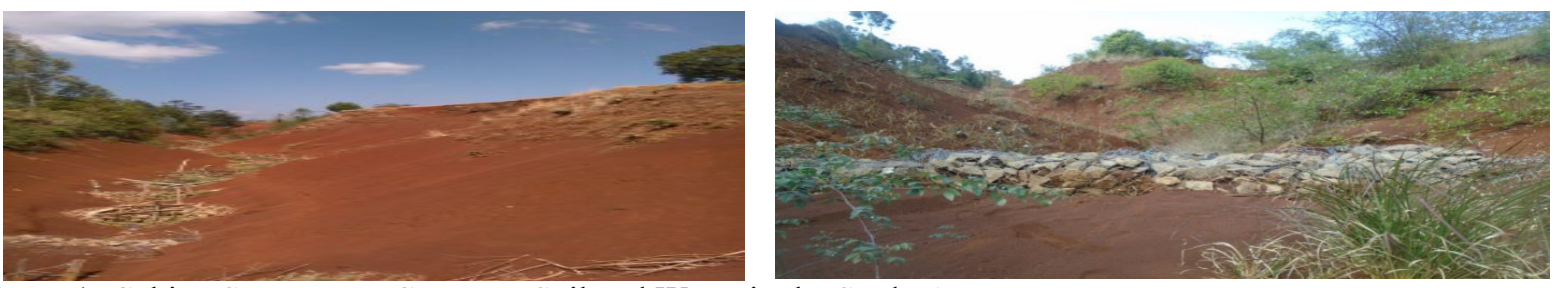

Figure 1: Gabion Structure to Conserve Soil and Water in the Study Area

\subsubsection{Soil Bunds}

Soil bunds are a physical construction of soil to boom infiltrations by decreasing the speed of runoff. As table1 below said that $85 \%, 56 \%$, and $18.6 \%$ of the respondents in the highland, midland and lowland respectively of the replied as they have participated within the soil bunds practices. This suggests that soil bund is more practised in the highland and midland than lowland, because of the soil form of lowland is difficult to prevent soil erosion and its topography isn't always that much hard as compared with the 2 agro-ecology. Key informants explained that in the look area soil bunds were applied to cultivated lands with slopes above $3-15 \%$ gradient and on grazing lands with mild slopes at wider intervals (as much as $5 \%$ slope). It can be carried out so on sloping farm regions blended with coins crops (see figure 2 below).
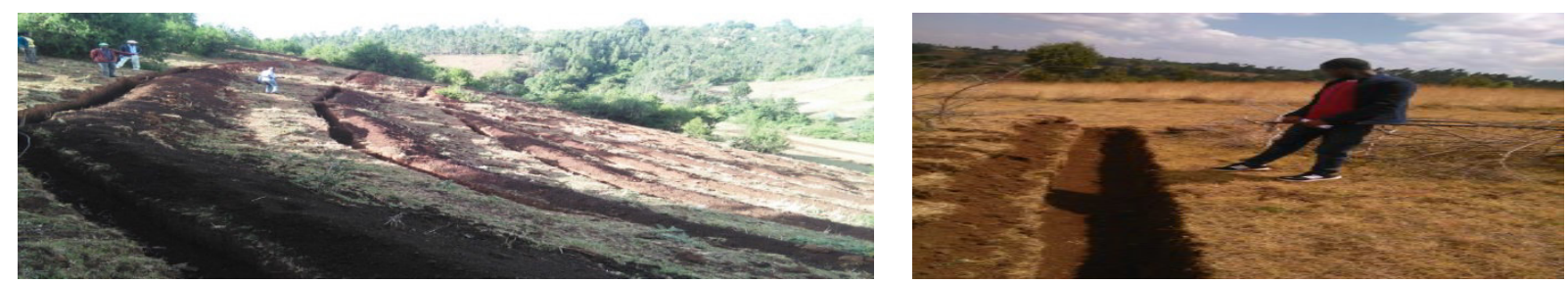

Figure 2: Soil Bunds Practice in the Study Area

\subsubsection{Area Closure}

Table 1 below shows that $78.2 \%, 47.8 \%$ and $34.3 \%$ of respondents in the highland, midland and lowland respectively were participated in the area closure to rehabilitate the degraded land. FGD participants' explained that the enclosed land stay was away from any human and animal intervention at least for four years. In some cases, they also protected and construct soil and water conservation structures such as soil bund, stone bund, Fanyajuu etc.

\subsubsection{Fanyajuu (Gilbert Irken)}

It is a physical method of soil and water conservation, which is similar to soil bund commonly constructed in a very steep slope land. It is basically used to slow down the runoff and allow to speculate within the farmland and increase soil moisture availability (see figure 3). $82.4 \%, 61.7 \%$ and $19.8 \%$ of respondents in the highland, midland and lowland were award about the benefit and practised Fanyajuupractices soil and water conservation method (see in table 1below). The key informant underlined that in the study area the majority of Fanyajuuis constructed from soil or soil strengthens with a stone rise in a collection of the channel.

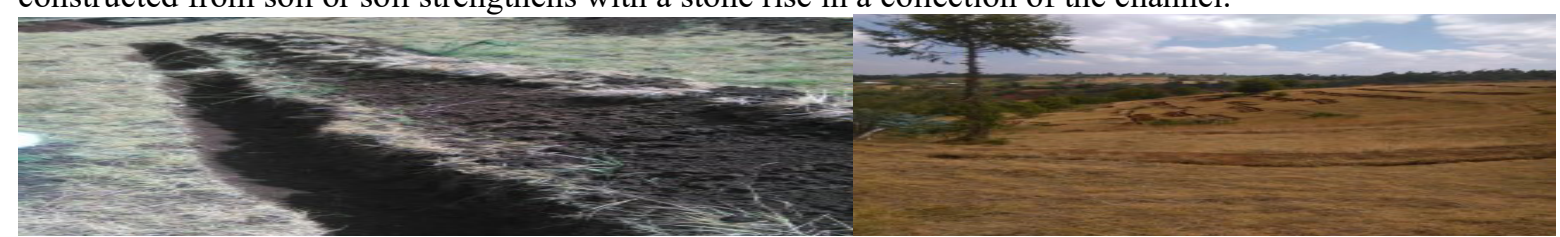

Figure 3. The Practices of Fanyajuu in the Study Area.

\subsubsection{Cutoff Drain}

In Table1 show that in the study area $38.5 \%, 40.2 \%$ and $74.3 \%$ of highland, midland and lowland respectively participated in the cutoff drain of SWC practices. This soil and water conservation era have been broadly practised by using lowlander research sites. FGD participants in the lowland explained that cutoff drain became more effective than other soil and water conservation technologies inside the black soil kind to prevent the farmland from high excessive rainfall erosion.

\subsubsection{Terracing}

Table 1. shows that about $90.5 \%$ of highland, $53.7 \%$ of midland and $32.4 \%$ lowland of the respondents were participated in the different type of terracing to conserve soil and water in their farmland.

\subsubsection{Waterways}

In the research site especially lowland part in the rainy season, farmers used the waterway to remove excess water in their farmland. The survey result indicates that $28.4 \%, 38.6 \%$ and $80.2 \%$ of the highland, midland and lowland respectively were using the waterway to unlogged their farmland (see table 1 below). 


\subsection{Biological Methods of Soil Water Conservation Practices}

\subsubsection{Manuring}

In the study area, the mixed farming system is a common one. As proportional most of the people were participate in Enset (false banana) production because of the common type of food is Kocho (a type of carbohydrate food produced from Enset production). Above $99 \%$ of the respondents were used livestock rearing, so this is used to improving Enset production. Manuring is the best practice especially to increase soil fertility of Enset area to increase its production. As stated in table 1. below that $90.5 \%, 38.3 \%$ and 35.6 of respondents highland, midland and lowland respectively used manuring to increase yield increment. Inconsistent with this finding Fikru (2009) which states that in Koga watershed farmers have increased the amount of manure applied because of the high price of inorganic fertilizers which the farmers cannot have enough money.

\subsubsection{Crop Residues}

Crop residues practices in the study area more practised in lowland than highland and midland. The quantitative result showed as $54.1 \%, 47.6 \%$ and $82.2 \%$ of highland, midland and lowland of the respondents use crop residues respectively (shown in table 1). This indicates that lowland area people are more use crop residue to protect their land from soil erosion and to increase soil fertility than the rest area of the woreda.

\subsubsection{Crop rotation}

As table 1 display that from the whole respondents of highland, midland and lowland $70.9 \%, 47.3 \%$ and $53.3 \%$ respectively participated in crop rotation. FGD participants emphasized because the farmers said that "if we sow inside the remaining year legumes, then inside the next 12 months we sow cereal crops. This is because of we have a scarcity of land the use of this land after stayed without crop production to growth it's fertility and by the use of this approach our yield productivity increased due to the boom of soil fertility". Consistent with the present-day finding, as stated by using Santra (2004) because the major benefit of crop rotation is that farmers can hold their fields underneath-stop manufacturing than letting they fallow. In addition, it reduces the need for synthetic fertilizers, pesticides and outbreak of diseases.

Table 1: Mechanical and Biological Methods of Soil and Water Conservation Practices.

\begin{tabular}{|c|c|c|c|c|c|c|}
\hline \multirow[b]{2}{*}{ Cases } & \multirow[b]{2}{*}{ Variables } & \multicolumn{5}{|c|}{ Agro-ecology } \\
\hline & & Responses & $\begin{array}{l}\text { Highland } \\
(\%)\end{array}$ & $\begin{array}{c}\text { Midland } \\
(\%)\end{array}$ & $\begin{array}{c}\text { Lowland } \\
(\%)\end{array}$ & $\begin{array}{l}\text { Total } \\
(\%)\end{array}$ \\
\hline \multirow{10}{*}{$\begin{array}{l}\text { A mechanical } \\
\text { method of soil } \\
\text { and }\end{array}$} & \multirow[t]{2}{*}{ Participation in Soil bund } & Yes & 85 & 66.4 & 18.6 & 56.7 \\
\hline & & No & 15 & 33.6 & 81.4 & 43.3 \\
\hline & \multirow[t]{2}{*}{ Participation in stone bund } & Yes & 84.5 & 62.1 & 23.6 & 57.7 \\
\hline & & No & 15.5 & 37.9 & 76.4 & 42.3 \\
\hline & \multirow[t]{2}{*}{ Participation in terracing } & Yes & 90.1 & 53.7 & 32.4 & 57.7 \\
\hline & & No & 9.9 & 46.3 & 67.6 & 42.3 \\
\hline & \multirow[t]{2}{*}{ Participation in area closure } & Yes & 78.2 & 47.8 & 34.3 & 53.4 \\
\hline & & No & 21.8 & 52.2 & 65.7 & 46.6 \\
\hline & \multirow[t]{2}{*}{ Participation in Fanyajuu } & Yes & 82.4 & 61.7 & 19.8 & 54.6 \\
\hline & & No & 17.6 & 38.3 & 81.2 & 45.5 \\
\hline \multirow[t]{6}{*}{ conservation } & \multirow[t]{2}{*}{ Participation in Cutoff drain } & Yes & 38.5 & 40.2 & 74.3 & 51 \\
\hline & & No & 61.5 & 59.8 & 25.7 & 49 \\
\hline & \multirow[t]{2}{*}{ Participation in water way } & Yes & 28.4 & 38.6 & 80.2 & 49 \\
\hline & & No & 71.6 & 61.4 & 19.8 & 51 \\
\hline & \multirow[t]{2}{*}{ Participation in manuring } & Yes & 90.5 & 38.3 & 35.6 & 39.1 \\
\hline & & No & 9.5 & 61.7 & 64.4 & 60.9 \\
\hline \multirow{4}{*}{$\begin{array}{l}\text { Biological } \\
\text { method of soil } \\
\text { and water } \\
\text { conservation }\end{array}$} & \multirow[t]{2}{*}{ Participation in Crop residues } & Yes & 54.1 & 47.6 & 82.2 & 61.3 \\
\hline & & No & 45.9 & 52.4 & 17.8 & 38.7 \\
\hline & \multirow[t]{2}{*}{ Participation in crop rotation } & Yes & 70.9 & 47.3 & 53.3 & 57.1 \\
\hline & & No & 29.1 & 52.7 & 46.7 & 42.9 \\
\hline
\end{tabular}

Source: own computation, 2017

3.3. Contribution of Soil and Water Conservation to Household Food Security 3.3.1. Increase Crop Productivity and Production

Table 2: The Contribution of SWC in Improvement of Vegetation Cover.

\begin{tabular}{cccc}
\hline Variable & Rate of change & Frequency & Per cent $(\%)$ \\
\hline & No change & 4 & 1.1 \\
The contribution of SWC in the & Low improvement & 21 & 5.9 \\
improvement of Vegetation Cover & Medium improvement & 162 & 45.5 \\
& High improvement & 169 & 47.5 \\
& Total & 356 & 100.0 \\
\hline
\end{tabular}

Source: own computation, 2017 
In table 2 above show that $45.5 \%$ and $47.5 \%$ of the participant stated that there area medium improvement and high improvement of vegetation cover respectively. And the rest $5.9 \%$ and $1.1 \%$ of the respondents were said that low improvement and no change respectively happen in the ChehaWoreda.

Table 3: The Difference Amount of Crop Productivity After the Implementation SWC Practice.

\begin{tabular}{|l|l|l|l|}
\hline Crop types & Difference amount in kuntal (Di) & Square of Di & Difference in value (Di) \\
\hline Barley & 369.7 & 136678 & 276532.3 \\
\cline { 3 - 4 } Wheat & 239.1 & 57168.8 & 356921.1 \\
\hline Teff & 190.7 & 36366.5 & 265436.9 \\
\cline { 1 - 3 } Maize & 539.3 & 290844.5 & 349433.1 \\
\hline Pea & 30.9 & 954.8 & 48489.2 \\
Enset & 542 & 293764 & 29810 \\
\hline Potato & 727.7 & 529547.3 & 312098.4 \\
\hline Total & 2639.4 & 1345323.9 & 12101525.6 \\
\hline Mean of the Di & 377.1 & 192189.129 & 1728789.4 \\
\hline
\end{tabular}

Source: own computation, 2017

There is a significant difference in the amount of crop productivity by the household after the practices of SWC activities in the study area. There are also significant changes in the case of the value of crop production. So, the mean statically values crop production and productivity of the households improved by 377.1 quintals in number and 1728789.4 ETB in value the implementation of soil and water conservation practices. UNEP (2002) stated that soil degradation is one of the factors that contribute to increasing rural poverty and food insecurity, due to the reduction of productivity and subsistence farmers less and less able to accumulate reserves of grains(Table 3).

The correlation of the crop productivity between before and after the using of soil and water conservation were 0.965, 0.825, 0.987, 0.875, 0.925, 0.427 and 0.962 for Barley, Wheat, Teff, Maize, Pea, Enset and Potato respectively. This result showed that there was a strong correlation between Teff, Enset, Barley, Maize, Pea and Potato, but Wheat was a weak correlation in the before and after implementation of SWC practices(Table3).

Table 4: Paired Samples Correlations

\begin{tabular}{llccc}
\hline Pairs & Variables & DF & Correlation & Sig. \\
\hline Pair one & Enset production before and after the SWC practices. & 311 & .981 & .01 \\
Pair two & Barley production before and after the SWC practices & 220 & .959 & .000 \\
Pair three & Wheat production before and after the SWC practices & 173 & .426 & .024 \\
Pair four & Pea production before and after the SWC practices & 34 & .922 & .000 \\
Pair five & Maize production before and after the SWC practices & 119 & .872 & .013 \\
Pair six & Potato production before and after the SWC practices & 151 & .933 & .000 \\
Pair seven & Teff production before and after the SWC practices & 138 & .980 & .000 \\
\hline
\end{tabular}

According to the survey result as shown in table 4. in the study area there were significant difference between both crop production and productivity before and after applying soil and water conservation practices. Teff productivity before $\mathrm{SWC}$ implementation was $\mathrm{M}=2.15(\mathrm{SD}=1.55)$. By comparison after practices were implemented $\mathrm{M}=3.53(\mathrm{SD}=2.33), \mathrm{t}(138)=-18.72, \mathrm{p}<0.01$. Wheat, before $\mathrm{SWC}$ practices were achieved $\mathrm{M}=$ $2.51(\mathrm{SD}=2.91)$, after the practices it was changed to $\mathrm{M}=3.50(\mathrm{SD}=2.17)$ and $\mathrm{t}(173)=-4.72, \mathrm{p}=0.024$. In the case of Enstet productivity $\mathrm{M}=116(\mathrm{SD}=60.74)$ improved by the $\mathrm{M}=138(65.51)$ and $\mathrm{t}(311)=-30.65), \mathrm{p}=$ 0.01 . The mean of Barely productivity improved from $\mathrm{M}=2.07(\mathrm{SD}=2.91$ to $\mathrm{M}=3.75(\mathrm{SD}=2.11)$ and $\mathrm{t}(220)$ $=-29.96, \mathrm{p}<0.01$.

Maize productivity before SWC implementation $\mathrm{M}=3.31$ ( $\mathrm{SD}=2.51)$. By comparison after SWC practices its productivity was $\mathrm{M}=7.84(\mathrm{SD}=7.12), \mathrm{t}(119)=-9.77, \mathrm{p}=0.013$. The rest Pea and Potato were improved from $\mathrm{M}=1.05(\mathrm{SD}=0.63)$ and $\mathrm{M}=2.38(\mathrm{SD}=2.03)$ to $\mathrm{M}=1.95(\mathrm{SD}=0.95)$ and $\mathrm{M}=7.20(\mathrm{SD}=7.29)$, and also the $\mathrm{t}$ value as $\mathrm{t}(34)=-12.17, \mathrm{p}<0.01$ and $\mathrm{t}(151)=-10.91), \mathrm{p}<0.01$ respectively. So the $\mathrm{t}$ - test result shown that the hypothesis of before and after SWC practices associated with statically significantly different mean productivity of crop yield on paired sample t-test was performed. 
Table 5: Paired Sample T-test Statistics of crop production in the study

\begin{tabular}{|c|c|c|c|c|}
\hline Pairs & Variables & Mean & DF & $\begin{array}{c}\text { Std. } \\
\text { Deviation }\end{array}$ \\
\hline \multirow[t]{2}{*}{ Pair one } & $\begin{array}{l}\text { The amount of Enset gets in a ha. before soil and water conservation } \\
\text { involvement (in number). }\end{array}$ & 116 & 311 & 60.74 \\
\hline & $\begin{array}{l}\text { The amount of Enset gets in a ha. after soil and water conservation } \\
\text { involvement (in number). }\end{array}$ & 138.65 & 311 & 65.51 \\
\hline \multirow[t]{2}{*}{ Pair two } & $\begin{array}{c}\text { The amount of Barley yield in a ha. before soil and water } \\
\text { conservation involvement (quintal). }\end{array}$ & 2.07 & 220 & 1.44 \\
\hline & $\begin{array}{l}\text { The amount of Barley yield in a ha. after soil and water conservation } \\
\text { involvement (quintal). }\end{array}$ & 3.75 & 220 & 2.11 \\
\hline \multirow[t]{2}{*}{$\begin{array}{l}\text { Pair } \\
\text { three }\end{array}$} & $\begin{array}{c}\text { The amount of Wheat yield in a ha. before soil and water } \\
\text { conservation involvement (quintal). }\end{array}$ & 2.51 & 173 & 2.91 \\
\hline & $\begin{array}{c}\text { The amount of Wheat yield in a ha. after soil and water conservation } \\
\text { involvement (quintal). }\end{array}$ & 3.50 & 173 & 2.17 \\
\hline \multirow{2}{*}{$\begin{array}{l}\text { Pair } \\
\text { four }\end{array}$} & $\begin{array}{c}\text { The amount of Pea yield in a ha. before soil and water conservation } \\
\text { involvement (quintal). }\end{array}$ & 1.05 & 34 & .63 \\
\hline & $\begin{array}{c}\text { The amount of Pea yield in a ha. after soil and water conservation } \\
\text { involvement (quintal). }\end{array}$ & 1.95 & 34 & .95 \\
\hline \multirow[t]{2}{*}{ Pair five } & $\begin{array}{c}\text { The amount of Maize yield in a ha. before soil and water } \\
\text { conservation involvement (quintal). }\end{array}$ & 3.31 & 119 & 2.51 \\
\hline & $\begin{array}{l}\text { The amount of Maize yield in a ha. after soil and water conservation } \\
\text { involvement (quintal). }\end{array}$ & 7.84 & 119 & 7.12 \\
\hline \multirow[t]{2}{*}{ Pair six } & $\begin{array}{c}\text { The amount of Potato yield in a ha. before soil and water } \\
\text { conservation involvement (quintal). }\end{array}$ & 2.38 & 151 & 2.03 \\
\hline & $\begin{array}{l}\text { The amount of Potato yield in a ha. after soil and water conservation } \\
\text { involvement (quintal). }\end{array}$ & 7.20 & 151 & 7.29 \\
\hline \multirow[t]{2}{*}{$\begin{array}{l}\text { Pair } \\
\text { seven }\end{array}$} & $\begin{array}{c}\text { The amount of Teff yield in a ha. before soil and water conservation } \\
\text { involvement (quintal). }\end{array}$ & 2.15 & 138 & 1.55 \\
\hline & $\begin{array}{l}\text { The amount of Teff yield in a ha. After soil and water conservation } \\
\text { involvement (quintal). }\end{array}$ & 3.53 & 138 & 2.33 \\
\hline
\end{tabular}
Source: HH survey, 2017

As the survey data are shown in table 5 below, there were changes in the mean of crop yield before and after the practices implemented. The mean difference of Barely, Wheat, Teff, Maize, Pea, Enset and Potato were $-1.68,-1.00,-1.38,-4.53,0.91,-22.66$ and -4.82 respectively. Even if there were a mean difference but it was not that much as a yield gain by performing effective soil and water conservation practices. This was due to the respondents used the application of chemical fertilizer but the quantity and way of application are not as directed by the experts.

Table 6: Paired Samples T-test of Crop Production.

\begin{tabular}{|c|c|c|c|c|c|c|c|}
\hline \multirow{3}{*}{ Variables (pairs) } & \multirow{3}{*}{ Df } & \multirow{3}{*}{$\mathrm{T}$} & \multirow{3}{*}{$\begin{array}{c}\text { Std. } \\
\text { Deviation }\end{array}$} & \multirow{3}{*}{$\begin{array}{l}\operatorname{Sig}(2- \\
\text { tailed })\end{array}$} & \multicolumn{3}{|c|}{ Paired Differences } \\
\hline & & & & & \multirow[t]{2}{*}{$\begin{array}{c}\text { Mean } \\
\text { difference }\end{array}$} & \multicolumn{2}{|c|}{$\begin{array}{c}95 \% \text { Confidence Interval } \\
\text { of the Difference }\end{array}$} \\
\hline & & & & & & Lower & Upper \\
\hline Barley production & 220 & -29.96 & .83 & .02 & -1.68 & -1.79 & -1.57 \\
\hline Wheat production & 173 & -4.72 & 2.791 & .025 & -1.03 & -1.42 & -.58 \\
\hline Teff production & 138 & -18.72 & .87 & .000 & -1.38 & -1.53 & -1.24 \\
\hline Maize production & 119 & -9.77 & 5.08 & .000 & -4.53 & -5.45 & -3.95 \\
\hline Pea production & 34 & -12.17 & .44 & .034 & -0.91 & -1.06 & -.76 \\
\hline Enset production & 311 & -30.66 & 13.06 & .045 & -22.66 & -24.15 & -21.21 \\
\hline Potato production & 151 & -10.90 & 5.45 & .000 & -4.82 & -5.69 & -3.95 \\
\hline
\end{tabular}


4.3.2. Increase Grazing Land

Table 7: The Contribution of SWC in the Improvement Grazing Land.

\begin{tabular}{|c|c|c|c|c|c|c|c|c|}
\hline \multirow{3}{*}{ Variables } & \multicolumn{6}{|c|}{ Agro-ecology } & \multirow{2}{*}{\multicolumn{2}{|c|}{ Total }} \\
\hline & \multicolumn{2}{|c|}{ Highland } & \multicolumn{2}{|c|}{ Midland } & \multicolumn{2}{|c|}{ Lowland } & & \\
\hline & Frequency & $\%$ & Frequency & $\%$ & Frequency & $\%$ & Frequency & $\%$ \\
\hline No change & 2 & 1.4 & 4 & 3.7 & 14 & 13.9 & 20 & 5.6 \\
\hline Low improvement & 5 & 3.3 & 8 & 7.5 & 20 & 19.8 & 33 & 9.3 \\
\hline Medium improvement & 49 & 33.1 & 49 & 45.8 & 35 & 34.6 & 133 & 37.4 \\
\hline High improvement & 92 & 62.1 & 46 & 43 & 32 & 31.7 & 170 & 47.7 \\
\hline Total & 148 & 100 & 107 & 100 & 101 & 100 & 356 & 100 \\
\hline
\end{tabular}

Source: own computation, 2017

The data shows that in the three agro-ecology of the study area the improvement of grazing land was different. In the highland $1.4 \%, 3.3 \%, 33.1 \%$ and $62.1 \%$ were responded as no change, low improvement, medium improvement and high improvement respectively. In the case of midland $3.7 \%, 7.5 \%, 45.8 \%$ and $43 \%$ of the respondents replied as there was no change, low improvement, medium improvement and high improvement respectively. However, the data obtained from the respondent in the lowland there was some difference $13.9 \%, 19.9 \%, 34.6 \%$ and $31.7 \%$ replied as for no change, low improvement, medium improvement and high improvement respectively (table 7).

\subsubsection{Increase Water Availability}

Table 8: The Level of Water Availability Before and After the SWC Practices.

\begin{tabular}{|c|c|c|}
\hline Variables & Frequency & Percentage \\
\hline \multicolumn{3}{|c|}{ The level of water availability before the practice of SWC } \\
\hline Low level & 47 & 35.1 \\
\hline Medium level & 184 & 51.7 \\
\hline High level & 125 & 13.2 \\
\hline Total & 356 & 100.0 \\
\hline \multicolumn{3}{|c|}{ The level of water availability after the practice of SWC } \\
\hline Low level & 12 & 3.4 \\
\hline Medium level & 144 & 40.4 \\
\hline High level & 200 & 56.2 \\
\hline Total & 356 & 100 \\
\hline
\end{tabular}

Source: own computation, 2017

In fact, water is a tool to improve the food security of the country as well as the world. The response of the respondents in the study area the level of water before practising soil and water conservation were $35.1 \%, 51.7 \%$ and $13.2 \%$ as low, medium and high level respectively. But in the case of water availability level, after soil and water conservation were $3.4 \%, 40.4 \%$ and $56.2 \%$ replied as low, medium and high level respectively present in their community(Table 8).

\subsubsection{Increase Food Availability}

Table 9: Food Availability of the Respondents Before and After the Practice.

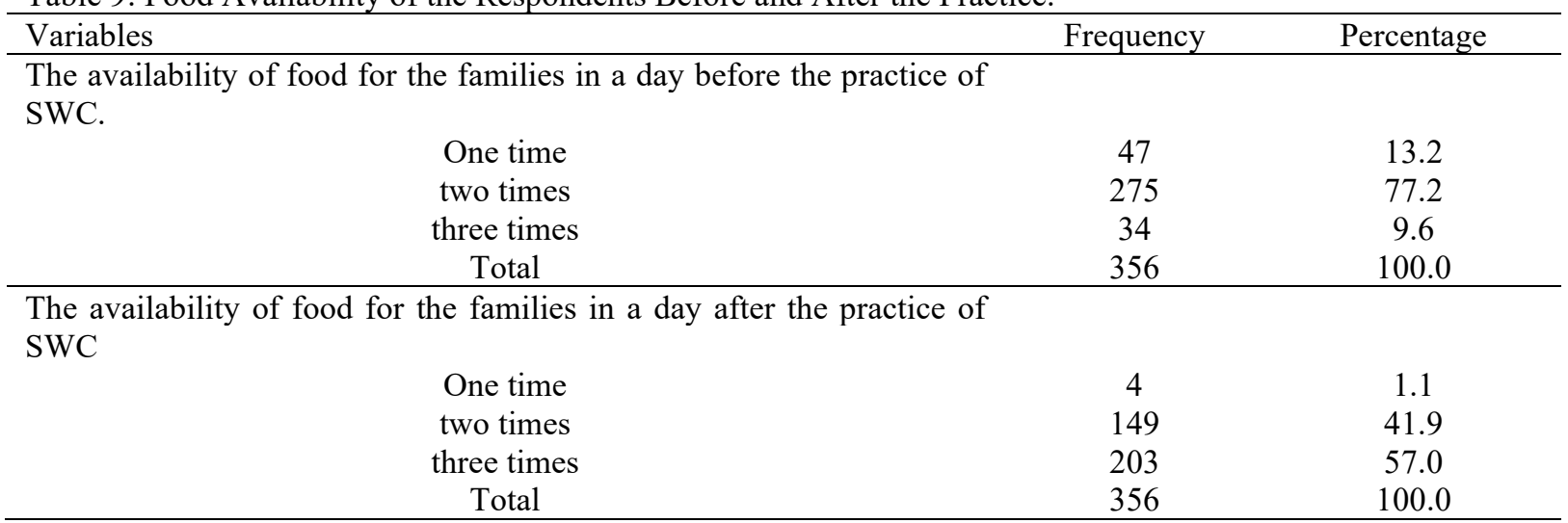

Source: own computation, 2017

The survey result of the household response shows in table 9 was $13.2 \%, 77.2 \%$ and $9.6 \%$ as one, two and three times respectively get the availability to eat food in a day before the implementation of SWC practices. In contrast to this after the implementation of the practice the availability of food to eat in a day was changed to $1.1 \%, 41.9 \%$ and $57 \%$ of the respondents as one, two and three times respectively. As table 9 show that there was a significant change in food availability, because of its $(p=0.01)$. The mean difference of 0.99 , the standard deviation of $0.84, \mathrm{t}$ value of -22.22 at the degree of freedom of 355 . 
Table 10: Paired Sample T-test of Food Availability.

\begin{tabular}{|l|c|c|c|c|c|}
\hline Variable & \multicolumn{5}{|c|}{ Paired Differences } \\
\hline \multirow{3}{*}{ The change in food availability } & Mean & Std. Deviation & T & Df & Sig. (2-tailed) \\
\cline { 2 - 6 } & -0.99 & 0.84 & -22.22 & 355 & 0.01 \\
\hline
\end{tabular}

Source: own computation, 2017

\section{Conclusion and Recommendation}

The focus of this study was to assess the contribution of soil and water conservation practices to household food security in ChehaWoreda. Female-headed households are lower in proration and their engagement in the soil and water conservation practices was lower than their counterparts. In the study sites across all agro-ecologies physical and biological soil conservation technologies has been implemented and farming household involvement in the SWC implementation has increased particularly in the last five years.

The contribution of SWC technologies for the increase of soil moisture, reduce erosion and increase agricultural productivity was encouraging. The majorities of households understand and participated with interest voluntarily. Soil bund, tracing, Fanyajuu, stone bund, area closure, waterways, cutoff drain, afforestation, crop rotation, crop residue, manuring and Chemical fertilizer application were among implemented SWC technologies. Development agents play a remarkable role in the awareness creation, supporting and advising farmers about the technical implementation and benefit of newly introduced technologies in the soil and water conservation.

In the study sites, natural and anthropogenic soil degradation barriers were responsible for soil degradation and water depletion. More specifically, high rainfall intensity, topographic nature and overgrazing were cause for soil degradation in the highland. Poor agricultural practices and overgrazing were causes of soil degradation in the lowland. In general, the researchers conclude that in the study sites soil and water conservation practices have been contributing to the increment of agricultural production and improvement of household food security.

\section{Based on the result of this study, the following recommendations are given}

$>$ Even though the majority of farmers understand the benefit of SWC and participate voluntarily; still, there are some who are not willing to implement the technology. Hence, the local government and development agents should devise a strategy to aware about the benefits of SWC and introduce locally, culturally and environmentally accepted technologies.

$>$ To achieve effective soil and water conservation technology, it must be done in accordance with guided by the correct guideline of the technology.

$>\quad$ If the way of chemical fertilizer application is guided by the expert, used to highly increases crop yield. But in the study area, most of the farmers used the application of chemical fertilizer in the traditional way. Hence, the kebele development agents should change the attitude of the farmers to use as guided by the experts.

\section{REFERENCES}

$>$ Admasu Amare. (2005). Study of sediment yield from the watershed of angerebresevoir, Haromy university. MSc Thesis (Unpublished).

$>$ Aklilu Amsalu, \&Graaf, J. (2006 ). The determinant of adoption and continued use of the stone terrace for SWC in an Ethiopian high land watershade Ecol.econ61(2-3); 294-302.

$>$ ELD initiative. (2013). Economics of land degradation initiative. A global strategy for sustainable land management, United Nation. Retrieved from http:/www.eld-initiative.org.

$>$ FDRE. (2013). Assessment of ownership and factors affecting utilization of insecticide-treated bednets in Dembe cha Woreda, West Gojjam Zone, Ethiopia.

$>$ Fikru, A. (2009). Assessment of adoption behaviour of soil and water conservation practices, Cornell University, MA Thesis (unpublished).

> Fleitmann, D., Dunbar, R.B., McCulloch, M., Mudelsee, M., Vuille, M., McClanahan, T.R., Cole, J.E, \&Eggins, S. (2007). East African soil erosion recorded in a 300-year-old coral colony from Kenya: Geographical research letters Vol. 34, L04401, doi:10.1029/2006GL028525

$>$ Genene Tsegaye\&AbiyGebre-Michael. (2014). Review on the overall status of soil and water conservation system and its constraints in different agro-ecological of southern Ethiopia. Journal of natural science research. 4(7).

$>$ Holden, J., Shotbolt, L., Bonn, A., Burt, T.P., Chapman, P.J., Dougill, A.J..., \& Worrall, F. (2007). Environmental change in moorland landscapes. doi:10.1016/j.earscirev.2007.01.003

$>$ Mohammed Andoshe. (2011). Perception of local community towards deforestation: MA Thesis (unpublished). Addis Ababa University.

$>$ Mohammed Mekonnen. (2014).Fertility mapping of soils. MSc Thesis (unpublished). Haramaya University 
$>$ Neely, J., \&Scheer Sara. (2003). Eco-agriculture, strategies to feed the world and save wild biodiversity, Island.

$>$ Sanchez, P.A. (2002). Soil Fertility and Hunger in Africa: Science, 129, 2019-2020. doi.org/10.1126/science. 1065256

$>$ Santra, S.C. (2004). Environmental Science. New central book agency. (p) .LTD.

$>$ Shibru Tefera. (2010). Land degradation and farmers perception. MA Theis (unpublished). Addis Ababa University.

$>$ Teshome, A., Rolker, D., \& de Graaff, J. (2012). Financial viability soil and water conservation technologies in northwestern Ethiopia highland app. Georg 37(139-49).

$>$ Yamane, T. (1967). Statistics: An introductory analysis, (2 ${ }^{\text {nd }}$ ed.). New York: Harper and Row. 